\title{
How to increase community participation capacity in food environment policymaking: Results of a scoping review
}

\author{
Nahid Zerafati-Shoae ${ }^{1,2}$, Ensiyeh Jamshidi*3(D), Leili Salehi ${ }^{4,5}$, Farzaneh Asgari Taee ${ }^{1}$
}

Received: 21 Jul 2019

Published: 9 Mar 2020

\section{Abstract}

Background: Food environment plays a major role in health outcomes. A growing interest in community-based participatory research (CBPR) has led to its application in the improvement of the food environment. This scoping review aims to compile and map the literature and identify key strategies used for increasing community participation capacity in the food environment policymaking process.

Methods: The scoping review of peer-reviewed articles on community participation and food environment policymaking followed the framework suggested by Arksey and O'Malley (2005). Scopus, PubMed, and Web of Science were searched. A charting table was developed to extract the key information of each identified study. A directed content analysis approach was used to assign retrieved codes into categories proposed by Foster-Fishman.

Results: A total of 28 studies were included in this review. Most studies used the CBPR approach to involve the community at least in the problem identification step of the policymaking process $(n=12)$ and 7 studies reported their involvement in all the steps of policymaking. In 15 out of 28 studies, the level of community participation was at "involvement" and in 8 studies it was at "empowerment". Strategies for increasing relational capacity, member capacity, programmatic capacity, and organizational capacity of community participation were reviewed.

Conclusion: To improve food environment using the community-participation approach, identifying different strategies and adjusting them based on the social and political context of each society is of high importance.

Keywords: Community-based participatory research, Food environment, Policymaking, Participation, Capacity building

Conflicts of Interest: None declared

Funding: This study has received funding from Iran University of Medical Sciences \& Health Services (Grant no: 9221324204).

*This work has been published under CC BY-NC-SA 1.0 license.

Copyright $\odot$ Iran University of Medical Sciences

Cite this article as: Zerafati-Shoae N, Jamshidi E, Salehi L, Asgari Taee F. How to increase community participation capacity in food environment policymaking: Results of a scoping review. Med J Islam Repub Iran. 2020 (9 Mar);34:18. https://doi.org/10.47176/mjiri.34.18

\section{Introduction}

Food environment highly influences healthy dietary behaviors and health outcomes (1). Food environment takes into account the availability, accessibility, and affordabil-

\section{Corresponding author: Dr Ensiyeh Jamshidi, e_jamshidi@razi.tums.ac.ir}

1. Department of Nutrition, School of Public Health, Iran University of Medical Sciences, Tehran, Iran

2. Community Nutrition Department, Faculty of Nutrition Sciences and Food Technology, National Nutrition and Food Technology Research Institute, Shahid Beheshti University of Medical Sciences, Tehran, Iran

3. Community Based Participatory Research Center, Iranian Institute for Reduction of High-Risk Behaviours, Tehran University of Medical Sciences, Tehran, Iran

4. Social Determinants of Health Research Center, Alborz University of Medical Sciences, Karaj, Iran

5. Department of Health Education and Promotion, School of Public Health, Alborz University of Medical Sciences, Karaj, Iran ity of healthy foods and beverages, along with exposure to calorie-dense, nutrient-poor foods, and beverages (2). Over the last 10 years, evidence has been mounting which

$\uparrow$ What is "already known” in this topic:

A number of CBPR studies have been reported to involve the community in positive food environment policy making change. However, the strategies that can strengthen and foster participation capacity in food environment policymaking to create this level of change have remained a challenge.

\section{$\rightarrow$ What this article adds:}

This study aimed to categorize strategies for improving the capacity of community participation in food environment policymaking. The proposed strategies can be adjusted based on the social and political context of each society. Further systematic reviews on the effectiveness of the proposed strategies can be designed. 
demonstrates associations between diet-related health disparities and food environment (3). Thus, a healthier food environment supports making healthier choices $(4,5)$.

In the neighborhood environment with limited access to healthy foods and increased access to fast-food outlets and convenience stores, the prevalence of obesity is high (611). The 2010 US Dietary Guidelines proposed that for facilitating individual healthy nutrition behaviors, food environment should be enhanced (12). Therefore, putting food environment improvement on the political agenda is an inevitable necessity.

Community-based participatory research (CBPR) has emerged in recent decades as a powerful approach for building healthy communities and promoting health by linking place-based work and policy (13). Equitable involvement of the community acts as a powerful method in decreasing health disparities, including diet-related health disparities (14). Community engagement can facilitate change in the food environment (15). Foster-Fishman et al reviewed integrative models and developed a framework to increase the capacity of community participation in community coalitions to facilitate their success. Four levels of community participation capacities were included (relational capacity, member capacity, programmatic capacity, and organizational capacity) that needed strategies to build and increase these levels.

A number of CBPR studies have been conducted to involve the community to tackle food environment problems (16-18). However, how participation capacity can be strengthened and fostered in a food environment policymaking has remained a challenge. The objective of this scoping review is to examine and map the literature and identify key strategies used for increasing community participation capacity in the food environment policymaking process based on Foster-Fishman et al framework. The results of this study will inform future researchers to assess the effectiveness of retrieved strategies to ensure their success in the field. In contrast to a systematic review, a scoping review is less likely to address very specific research questions (19).

\section{Methods}

A scoping review was done to obtain peer-reviewed articles on community participation and food environment policymaking. The review followed the framework suggested by Arksey and O'Malley (2005) who outlined 5 steps: identifying the study questions, finding relevant researches, selection of studies, charting the data, summarizing, and reporting results (20). The primary question was "Which strategies have been used for increasing community participation capacity in the food environment policymaking process?"

\section{Search strategy}

To identify relevant records, databases and the reference lists of relevant literatures were searched. A search strategy was developed iteratively and piloted using PubMed. To choose appropriate key terms, the title, abstracts, and key words of 10 retrieved relevant original or review articles were assessed and the synonyms of core concepts were determined. Then, Scopus, PubMed and Web of Science were searched using a combination of refined set of search terms: (community participat* OR community engag* OR participatory action research OR community based participat*) AND (food access* OR food availab* OR food affordab* OR food environment) to find peerreviewed articles published up to 2018 in English (Appendix 1: Search syntaxes). A manual search was conducted on the reference lists.

\section{Inclusion and exclusion criteria}

Peer-reviewed articles published in English that used CBPR approach or other engaged research such as participatory action research, which dealt with community participation and policymaking in the food environment and mentioned the strategies used for increasing community participation capacity, were included. Records irrelevant to the topic of participation in food environment policymaking, not written in English, books, organizational reports, and conference abstracts were excluded.

\section{Article screening and selection}

Titles and abstracts of retrieved records were reviewed independently by 2 researchers (NZ, EJ). Then, full-texts were assessed to decide on the relevancy of the articles. The researchers discussed the disagreement, if any, and in case an agreement was not reached, the third researcher (LS) resolved the problem. After screening, 59 full-text studies were reviewed for eligibility. A flow diagram of the study selection procedure is presented in Figure 1.

\section{Data extraction and analysis}

In scoping review, included studies are not assessed for methodological quality (21). For data abstraction, a charting table was developed to record the key information of the source, including researchers/year, objective, the setting, and type of democratic process, in which community has the possibility of participating in the decision-making, steps of community involvement in the policymaking process, participation level, and participation techniques.

Public policymaking process was reviewed based on the Charles Jones policymaking framework which includes 4 major steps: (1) agenda-setting and problems identification, (2) policy formulation (translating the agenda item into an authoritative decision: a law, regulation,...), (3) policy implementation (administrating and enforcing the authorized policy by an agency of government), and (4) policy evaluation (assessing the impacts of the policy) (22).

Public participation level and participation techniques were evaluated using the International Association of Public Participation (IAP2) classification. According to the IAP2 spectrum of public participation, participation can be classified into 5 levels, including informing, consulting, involving, collaborating, and empowering (23). Also, participatory techniques are classified into 3 categories: sharing information, compiling and providing feedback, and bringing people together (24).

The democracy process for involving the community in decision-making which applied by each study was catego- 


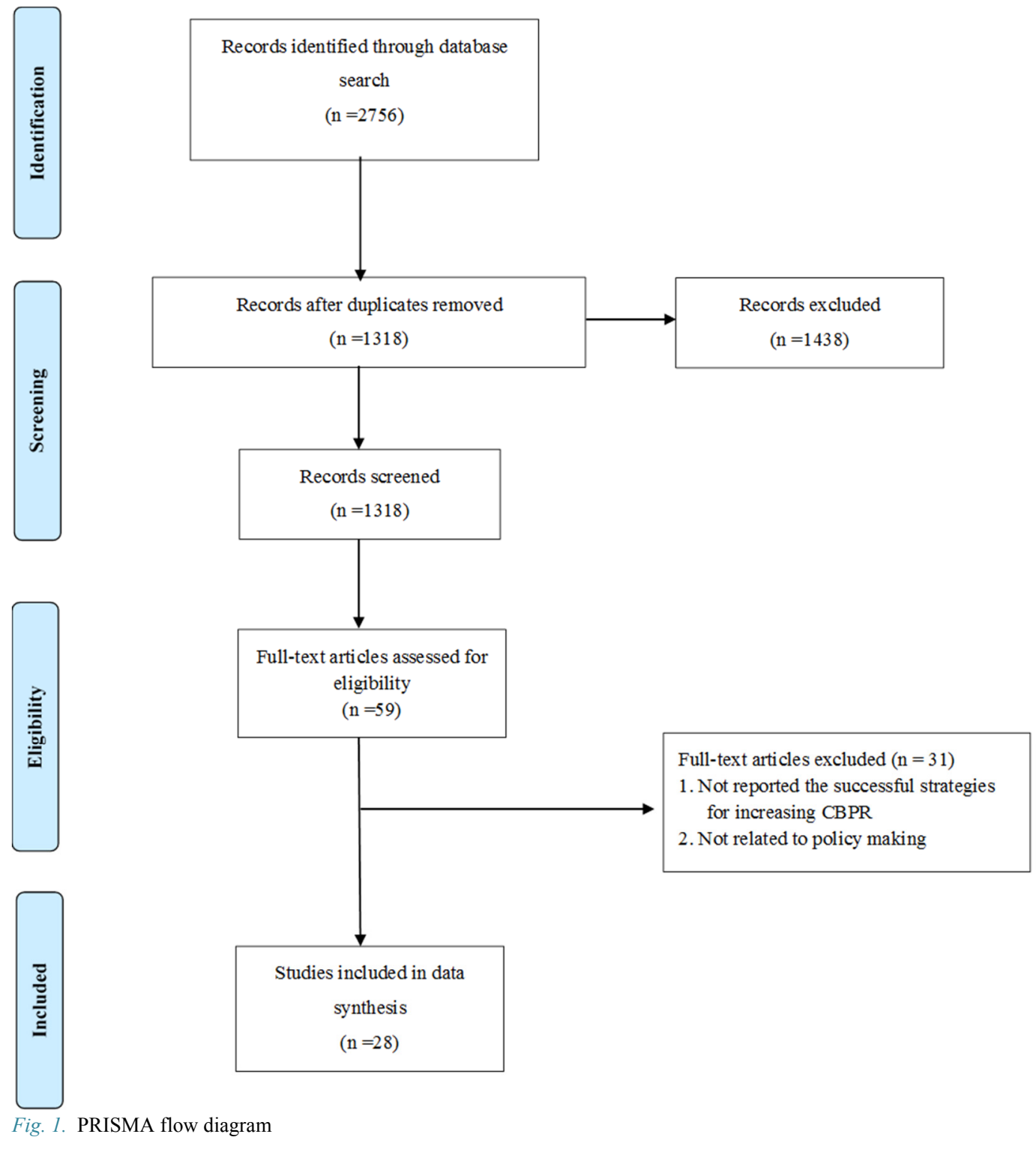

rized as a participatory or representative democracy. A participatory democracy uses informed and active citizens' participation, where power is delegated to the citizens in recreating and managing the environment. In a representative democracy, authority is held by people's representatives (25).

The strategies for improving participation capacity were extracted based on 4 critical levels of the collaborative capacity framework proposed by Foster-Fishman et al, which include member, relational, organizational, and programmatic capacities (26).

A directed content analysis approach was used for analysis. In this approach, the goal of a directed approach to content analysis is to conceptually validate or extend a theoretical framework or theory. The existing theoretical collaborative capacity framework can help to identify key concepts or variables as initial coding categories (27).

At first, the text of retrieved articles was read carefully to increase deep understanding. Key statements were underlined to find the meaning units or initial codes. Next, similar codes were located in categories of the framework. Then, the external check method using 2 experts in health promotion and nutrition policy and familiar with the framework was used to confirm dependability and conformability of the data. The initial codes and the categories of the framework were audited.

\section{Results}

As shown in Figure 1, about 2756 records were in the primary list of database searches; in the end, 28 studies were selected. The characteristics of the included studies are summarized in Table 1. Most of these studies (25 out of 28) were conducted in the US and in communities that had one of the following characteristics: poor socioeconomic status, a high prevalence of chronic diseases, and food insecurity. 
Table 1. Characteristics of included articles to the review on community participation and food environment policymaking

\begin{tabular}{|c|c|c|c|c|c|}
\hline Author/Year & Setting & Study objective & $\begin{array}{l}\text { Democracy } \\
\text { type/level of } \\
\text { participation }\end{array}$ & $\begin{array}{l}\text { Involvement of } \\
\text { community in } \\
\text { policy making } \\
\text { steps }\end{array}$ & $\begin{array}{l}\text { Participation technique/data } \\
\text { gathering technique }\end{array}$ \\
\hline $\begin{array}{l}\text { Díez, Julia } \\
\text { et al (2017) } \\
\text { (46) }\end{array}$ & Spain (Madrid) & $\begin{array}{l}\text { To understand key deter- } \\
\text { minants of the local food } \\
\text { environment influencing } \\
\text { residents' diets }\end{array}$ & $\begin{array}{l}\text { Participatory } \\
\text { / Collaboration }\end{array}$ & $\begin{array}{c}\text { Problem } \\
\text { identification }\end{array}$ & $\begin{array}{l}\text { 1.Share information (via } \\
\text { media, etc.), 2.Compile and } \\
\text { provide feedback } \\
\text { (photovoice, } \\
\text { 3.Bring people together } \\
\text { (meeting) }\end{array}$ \\
\hline $\begin{array}{l}\text { Sheats, Jylana } \\
\text { L et al (2017) } \\
\text { (47) }\end{array}$ & $\begin{array}{l}\text { US (three neighbor- } \\
\text { ing urban cities in } \\
\text { North San Mateo } \\
\text { County, } \\
\text { California) }\end{array}$ & $\begin{array}{l}\text { To assess and advocate for } \\
\text { healthy food environments }\end{array}$ & $\begin{array}{l}\text { Participatory } \\
\text { / Collaboration }\end{array}$ & $\begin{array}{l}\text { Problem } \\
\text { identification }\end{array}$ & $\begin{array}{ll}\begin{array}{l}\text { 1.Compile and } \\
\text { feedback }\end{array} \\
\text { (photovoice, } \\
\text { 2.Bring people } \\
\text { (meeting) }\end{array}$ \\
\hline $\begin{array}{l}\text { Ball, Lanae } \\
\text { et al (2017) } \\
\text { (48) }\end{array}$ & $\begin{array}{l}\text { US (Catawba, Caro- } \\
\text { lina) }\end{array}$ & $\begin{array}{c}\text { To evaluate the implemen- } \\
\text { tation of a farmers' market } \\
\text { targeting a WIC program } \\
\text { participants }\end{array}$ & $\begin{array}{l}\text { Participatory } \\
\text { /Empowerment }\end{array}$ & $\begin{array}{l}\text { Problem } \\
\text { identification, } \\
\text { policy formula- } \\
\text { tion, policy } \\
\text { implementation }\end{array}$ & $\begin{array}{l}\text { 1.Share information } \\
\text { (TV/radio advertisements, e- } \\
\text { mail newsletter, YouTube } \\
\text { video and etc.), 2.Compile } \\
\text { and provide feedback (direct } \\
\text { observation, review of vari- } \\
\text { ous documents and semi- } \\
\text { structured interviews), } \\
\text { 3.Bring people together } \\
\text { (meeting, workshops) }\end{array}$ \\
\hline $\begin{array}{l}\text { Lachance, } \\
\text { Laurie et al } \\
(2018)(49,50)\end{array}$ & $\begin{array}{l}\text { US (Michigan, New } \\
\text { York. Boston) }\end{array}$ & $\begin{array}{l}\text { To describe the outcomes } \\
\text { of local systems and policy } \\
\text { change to increase equita- } \\
\text { ble opportunities for health }\end{array}$ & $\begin{array}{l}\text { Participatory } \\
\text { /Empowerment }\end{array}$ & $\begin{array}{c}\text { Problem } \\
\text { identification, } \\
\text { agenda -setting, } \\
\text { policy } \\
\text { formulation, and } \\
\text { policy } \\
\text { implementation }\end{array}$ & \\
\hline $\begin{array}{l}\text { Leung, May } \\
\text { May et al } \\
(2017)(51)\end{array}$ & US (New York) & $\begin{array}{l}\text { To use photovoice for } \\
\text { exploring food justice } \\
\text { issues with minority youth }\end{array}$ & $\begin{array}{l}\text { Participatory } \\
\text { /Collaboration }\end{array}$ & $\begin{array}{l}\text { Problem } \\
\text { identification, } \\
\text { agenda -setting }\end{array}$ & $\begin{array}{l}\text { 1.Compile and provide } \\
\text { feedback } \\
\text { (photovoice, interview, } \\
\text { focus group discussions) }\end{array}$ \\
\hline $\begin{array}{l}\text { Minkler, Mer- } \\
\text { edith et al } \\
\text { (2018) (52) }\end{array}$ & US (San Francisco) & $\begin{array}{l}\text { To bring healthy retail to } \\
\text { urban "Food Swamps" }\end{array}$ & $\begin{array}{l}\text { Participatory } \\
\text { /Empowerment }\end{array}$ & $\begin{array}{l}\text { Problem } \\
\text { identification, } \\
\text { policy formula- } \\
\text { tion, policy } \\
\text { implementation, } \\
\text { and policy } \\
\text { evaluation }\end{array}$ & $\begin{array}{l}\text { Share information (joint } \\
\text { press } \\
\text { conference include local } \\
\text { radio and newsletter) } \\
\text { 1.Compile and provide } \\
\text { feedback } \\
\text { (interview, review of inter- } \\
\text { nal documents, focus group), } \\
\text { 2.Bring people together } \\
\text { (meeting) }\end{array}$ \\
\hline $\begin{array}{l}\text { Buman, } \\
\text { Bertmann et al } \\
\text { (2015) (53) }\end{array}$ & $\begin{array}{l}\text { US (a large metro- } \\
\text { politan city) }\end{array}$ & $\begin{array}{l}\text { To understand factors that } \\
\text { enhanced or detracted from } \\
\text { shoppers' experiences in } \\
\text { an urban farmers' market }\end{array}$ & $\begin{array}{l}\text { Participatory } \\
\text { /Involvement }\end{array}$ & $\begin{array}{l}\text { Problem } \\
\text { identification }\end{array}$ & $\begin{array}{l}\text { Compile and provide feed- } \\
\text { back (computer-based poll- } \\
\text { ing) }\end{array}$ \\
\hline $\begin{array}{l}\text { Gravlee, } \\
\text { Boston et al } \\
(2014)(54)\end{array}$ & $\begin{array}{l}\text { US (Tallahassee, } \\
\text { Florida) }\end{array}$ & $\begin{array}{l}\text { To examine the perspec- } \\
\text { tives of food-store owners } \\
\text { and managers on the food } \\
\text { environment }\end{array}$ & $\begin{array}{l}\text { Participatory } \\
\text { /Involvement }\end{array}$ & $\begin{array}{l}\text { Problem } \\
\text { identification }\end{array}$ & $\begin{array}{l}\text { Compile and provide feed- } \\
\text { back (interview) }\end{array}$ \\
\hline $\begin{array}{l}\text { Pitts, Smith et } \\
\text { al (2013) (55) }\end{array}$ & $\begin{array}{l}\text { US (Lenoir County, } \\
\text { North Carolina) } \\
\text { Centered in the heart } \\
\text { of the stroke belt }\end{array}$ & $\begin{array}{l}\text { To determine winnable } \\
\text { obesity-prevention policies } \\
\text { from among the COCO- } \\
\text { MO* recommended strate- } \\
\text { gies from the perspectives } \\
\text { of local policy-makers and } \\
\text { stakeholders }\end{array}$ & $\begin{array}{l}\text { Participatory } \\
\text { /Involvement }\end{array}$ & $\begin{array}{l}\text { Policy } \\
\text { formulation }\end{array}$ & $\begin{array}{l}\text { Compile and provide feed- } \\
\text { back (interview and survey) }\end{array}$ \\
\hline
\end{tabular}

Thirteen out of the 28 included studies involved the community in more than one step of Jones' policy-making process. Most studies used the CBPR approach to involve them to address at least the problem identification step of the policymaking process $(n=12)$ and only 7 studies reported their participation in all the steps of policymaking. In 15 out of 28 studies, community participation was at involvement level and in 8 it was at empowerment level.
In most cases, the type of democracy which applied was participatory $(n=24)$. In addition, the most common participatory techniques that were used included compiling and providing feedback.

Table 2 shows the strategies for increasing community participation capacity in food-environment policymaking, which are assigned into organizational, relational, member, and programmatic capacities. 
N. Zerafati-Shoae, et al.

\begin{tabular}{|c|c|c|c|c|c|}
\hline Author/Year & Setting & Study objective & $\begin{array}{l}\text { Democracy } \\
\text { type/level of } \\
\text { participation }\end{array}$ & $\begin{array}{l}\text { Involvement of } \\
\text { community in } \\
\text { policy making } \\
\text { steps }\end{array}$ & $\begin{array}{c}\text { Participation tech- } \\
\text { nique/data gathering tech- } \\
\text { nique }\end{array}$ \\
\hline $\begin{array}{l}\text { Pitts Stephanie } \\
\text { B. Jilcott, et al } \\
(2012)(56)\end{array}$ & $\begin{array}{l}\text { US (Pitt County, } \\
\text { North Carolina) } \\
\text { Centered in the } \\
\text { heart of the stroke } \\
\text { belt }\end{array}$ & $\begin{array}{l}\text { To present a community- } \\
\text { driven, COCOMO-guided } \\
\text { approach toward identifying } \\
\text { winnable local policy strategies } \\
\text { for obesity prevention }\end{array}$ & $\begin{array}{l}\text { Representative } \\
\text { / Involvement }\end{array}$ & $\begin{array}{c}\text { Policy } \\
\text { formulation }\end{array}$ & $\begin{array}{l}\text { Compile and provide } \\
\text { feedback (interview) }\end{array}$ \\
\hline $\begin{array}{l}\text { Byrd- } \\
\text { Bredbenner, } \\
\text { Johnson et al } \\
(2012)(57)\end{array}$ & $\begin{array}{l}\text { US (East Harlem, } \\
\text { New York) } \\
\text { With high diabetes } \\
\text { rates }\end{array}$ & $\begin{array}{l}\text { To describe a partnered ap- } \\
\text { proach by using structured } \\
\text { observation to collect baseline } \\
\text { data regarding the built and } \\
\text { food environments }\end{array}$ & $\begin{array}{l}\text { Participatory } \\
\text { / Involvement }\end{array}$ & $\begin{array}{l}\text { Problem } \\
\text { identification }\end{array}$ & $\begin{array}{l}\text { Compile and provide } \\
\text { feedback } \\
\text { (survey) }\end{array}$ \\
\hline $\begin{array}{l}\text { Noseworthy, } \\
\text { Williams et al } \\
(2011)(58)\end{array}$ & $\begin{array}{c}\text { Canada (Nova Sco- } \\
\text { tia) } \\
\text { With high chronic } \\
\text { disease }\end{array}$ & $\begin{array}{l}\text { To examine the availability and } \\
\text { relative cost of nutritious, } \\
\text { locally produced foods in } \\
\text { grocery stores }\end{array}$ & $\begin{array}{l}\text { Representative / } \\
\text { Involvement }\end{array}$ & $\begin{array}{l}\text { Problem } \\
\text { identification }\end{array}$ & $\begin{array}{l}\text { Compile and provide } \\
\text { feedback } \\
\text { (survey) }\end{array}$ \\
\hline $\begin{array}{l}\text { Izumi, Zenk et } \\
\text { al (2012) (59) }\end{array}$ & $\begin{array}{l}\text { US (Detroit, Michi- } \\
\text { gan) } \\
\text { Three low income } \\
\text { districts }\end{array}$ & $\begin{array}{l}\text { Assessing the reliability of the } \\
\text { food environment audit for } \\
\text { diverse neighborhoods }\end{array}$ & $\begin{array}{l}\text { Participatory } \\
\text { / Involvement }\end{array}$ & $\begin{array}{l}\text { Problem } \\
\text { identification }\end{array}$ & $\begin{array}{l}\text { Compile and provide } \\
\text { feedback } \\
\text { (survey) }\end{array}$ \\
\hline $\begin{array}{l}\text { Azuma, } \\
\text { Gilliland et al } \\
(2010)(60)\end{array}$ & $\begin{array}{l}\text { US (Los Angeles, } \\
\text { California) } \\
\text { Three low-income } \\
\text { communities }\end{array}$ & $\begin{array}{l}\text { To evaluate food access, avail- } \\
\text { ability, and affordability }\end{array}$ & $\begin{array}{l}\text { Participatory } \\
\text { / Involvement }\end{array}$ & $\begin{array}{c}\text { Problem } \\
\text { identification }\end{array}$ & $\begin{array}{l}\text { Compile and provide } \\
\text { feedback } \\
\text { (survey, food-mapping, } \\
\text { interview) }\end{array}$ \\
\hline $\begin{array}{l}\text { Skinner, } \\
\text { Hanning et al } \\
(2006)(45)\end{array}$ & Canada (Ontario) & $\begin{array}{l}\text { To investigate barriers, and } \\
\text { support healthy eating and } \\
\text { physical activity in youth }\end{array}$ & $\begin{array}{l}\text { Participatory } \\
\text { / Involvement }\end{array}$ & $\begin{array}{c}\text { Problem } \\
\text { identification }\end{array}$ & $\begin{array}{l}\text { Compile and provide } \\
\text { feedback } \\
\text { (scan of the community } \\
\text { environment, focus } \\
\text { Groups, and unstructured } \\
\text { one-on-one interviews) }\end{array}$ \\
\hline $\begin{array}{l}\text { Buman, Winter } \\
\text { et al }(2012)(35)\end{array}$ & $\begin{array}{c}\text { US (San Mateo } \\
\text { County, California) }\end{array}$ & $\begin{array}{l}\text { To describe the methods for } \\
\text { engaging older adults in neigh- } \\
\text { borhood environment assess- } \\
\text { ment, community organizing, } \\
\text { and coalition-building activi- } \\
\text { ties, and decision-making and } \\
\text { advocacy-training activities. }\end{array}$ & $\begin{array}{l}\text { Participatory } \\
\text { / Involvement }\end{array}$ & $\begin{array}{l}\text { Problem identifi- } \\
\text { cation and agen- } \\
\text { da-setting }\end{array}$ & $\begin{array}{l}\text { 1.Compile and provide } \\
\text { feedback } \\
\text { (photovoice and survey), } \\
\text { 2.Bring people together } \\
\text { (workshops and delibera- } \\
\text { tive dialogues) }\end{array}$ \\
\hline $\begin{array}{l}\text { Mabachi and } \\
\text { Kimminau } \\
(2012)(33)\end{array}$ & $\begin{array}{l}\text { US (Wyandotte } \\
\text { County, Kansas) }\end{array}$ & $\begin{array}{l}\text { To investigate the food needs } \\
\text { of residents and develop a } \\
\text { business plan to improve ac- } \\
\text { cess to healthy food options }\end{array}$ & $\begin{array}{l}\text { Participatory } \\
\text { / Involvement }\end{array}$ & $\begin{array}{l}\text { Problem } \\
\text { identification and } \\
\text { policy formulation }\end{array}$ & $\begin{array}{l}\text { 1.Compile and provide } \\
\text { feedback } \\
\text { (survey) } \\
\text { 2.Bring people together } \\
\text { (deliberative dialogues) }\end{array}$ \\
\hline $\begin{array}{l}\text { Fleischhacker, } \\
\text { Vu et al (2011) } \\
(61)\end{array}$ & US (North Carolina) & $\begin{array}{l}\text { To develop planning and poli- } \\
\text { cy strategies to improve access } \\
\text { to healthy eating }\end{array}$ & $\begin{array}{l}\text { Representation } \\
\text { / Involvement }\end{array}$ & $\begin{array}{l}\text { Policy } \\
\text { formulation }\end{array}$ & $\begin{array}{l}\text { Bring people together } \\
\text { (Deliberative dialogues) }\end{array}$ \\
\hline $\begin{array}{l}\text { Vásquez, Lanza } \\
\text { et al (2007) (16) }\end{array}$ & US (San Francisco) & $\begin{array}{l}\text { To describe local food security } \\
\text { policy efforts through public } \\
\text { policy action in a community- } \\
\text { based participatory study }\end{array}$ & $\begin{array}{l}\text { Participatory } \\
\text { / Involvement }\end{array}$ & $\begin{array}{l}\text { Problem identifi- } \\
\text { cation, agenda - } \\
\text { setting, policy } \\
\text { formulation, poli- } \\
\text { cy implementa- } \\
\text { tion, and policy } \\
\text { evaluation }\end{array}$ & $\begin{array}{l}\text { 1. Share information } \\
\text { (central information con- } \\
\text { tacts, television, technical } \\
\text { reports, and award- } \\
\text { winning media campaign) } \\
\text { 2.Compile and provide } \\
\text { feedback } \\
\text { (interview, survey, and } \\
\text { mapping) 3. Bring people } \\
\text { together (deliberative } \\
\text { dialogues) }\end{array}$ \\
\hline
\end{tabular}

\section{Discussion}

This study reviewed the articles which used the CBPR approach to explore strategies to increase community participation capacity in food environment policymaking. Results showed that most of the studies involved the community in the problem-identification step of policymaking and the level of community participation was at involvement level. Involvement means to work directly with the community throughout the research process to ensure that their concerns are steadily perceived and considered (23). This level is higher than informing and consulting to obtain feedbacks. In line with this study, results of a systematic review on CBPR studies conducted by the research team showed that the community was most involved in the selection of research question (problemidentification), intervention development, and im- 


\begin{tabular}{|c|c|c|c|c|c|}
\hline \multicolumn{6}{|l|}{ Table 1. Ctd } \\
\hline Author/Year & Setting & Study objective & $\begin{array}{l}\text { Democracy } \\
\text { type/level of } \\
\text { participation }\end{array}$ & $\begin{array}{l}\text { Involvement of } \\
\text { community in } \\
\text { policy making } \\
\text { steps }\end{array}$ & $\begin{array}{l}\text { Participation technique/data } \\
\text { gathering technique }\end{array}$ \\
\hline $\begin{array}{l}\text { Tsui, } \\
\text { Bylander et } \\
\text { al (2012) } \\
(32)\end{array}$ & $\begin{array}{l}\text { US (three New } \\
\text { York neighbor- } \\
\text { hoods) }\end{array}$ & $\begin{array}{l}\text { To assess the degree of success of the } \\
\text { Health Equity Project (HEP) }\end{array}$ & $\begin{array}{l}\text { Participatory } \\
\text { /Involvement }\end{array}$ & $\begin{array}{l}\text { Problem identi- } \\
\text { fication, agenda } \\
\text {-setting, policy } \\
\text { formulation, } \\
\text { and policy } \\
\text { implementation }\end{array}$ & $\begin{array}{l}\text { 1.Compile and provide feed- } \\
\text { back } \\
\text { (interview, survey) } \\
\text { 2. Bring people together } \\
\text { (deliberative dialogues) }\end{array}$ \\
\hline $\begin{array}{l}\text { Jernigan, } \\
\text { Salvatore et } \\
\text { al } \\
(2011)(62)\end{array}$ & $\begin{array}{l}\text { US (round } \\
\text { Valley Indian } \\
\text { reservation in } \\
\text { Northern Cali- } \\
\quad \text { fornia) }\end{array}$ & $\begin{array}{l}\text { To identify community priority fac- } \\
\text { tors, and design and implement poli- } \\
\text { cies related to community issues }\end{array}$ & $\begin{array}{l}\text { Representative } \\
\text { /Involvement }\end{array}$ & $\begin{array}{l}\text { Policy devel- } \\
\text { opment and } \\
\text { policy imple- } \\
\text { mentation }\end{array}$ & $\begin{array}{l}\text { Bring people together (deliber- } \\
\text { ative dialogues) }\end{array}$ \\
\hline $\begin{array}{l}\text { Hill, Jennie } \\
\text { Et al } \\
(2015)(63)\end{array}$ & $\begin{array}{l}\text { US (Virginia } \\
\text { and North } \\
\text { Carolina, Dan } \\
\text { River Region) }\end{array}$ & $\begin{array}{l}\text { To describe the quality of restaurant } \\
\text { food offered to children and to deter- } \\
\text { mine if the availability of healthy } \\
\text { foods differed by location or by the } \\
\text { predominant race of an area's popula- } \\
\text { tion }\end{array}$ & $\begin{array}{l}\text { Participatory } \\
\text { /Informing }\end{array}$ & $\begin{array}{l}\text { Problem identi- } \\
\quad \text { fication }\end{array}$ & $\begin{array}{l}\text { Compile and provide feedback } \\
\text { (survey) }\end{array}$ \\
\hline $\begin{array}{l}\text { Seguin, } \\
\text { Folta et al } \\
(2014)(64)\end{array}$ & $\begin{array}{l}\text { US (Alaska, } \\
\text { Arkansas, } \\
\text { Kansas, Mis- } \\
\text { souri, Montana, } \\
\text { Pennsylvania, } \\
\text { and Wisconsin; } \\
\text { rural towns in } \\
\text { these seven } \\
\text { U.S. states) }\end{array}$ & $\begin{array}{l}\text { To understand the best practices } \\
\text { related to civic engagement as a } \\
\text { means of creating communities in } \\
\text { which the healthy choice is the easier } \\
\text { choice }\end{array}$ & $\begin{array}{l}\text { Participatory } \\
\text { /Empowerment }\end{array}$ & $\begin{array}{l}\text { Problem identi- } \\
\text { fication, policy } \\
\text { formulation, } \\
\text { policy imple- } \\
\text { mentation, and } \\
\text { policy evalua- } \\
\text { tion }\end{array}$ & $\begin{array}{l}\text { 1. Share information (press } \\
\text { releases and press packets, } \\
\text { printed public information } \\
\text { materials, media, and tele- } \\
\text { phone } \\
\text { 2.Compile and provide feed- } \\
\text { back (interactive workshops ) } \\
\text { 3.Bring people together (meet- } \\
\text { ing and workshops) }\end{array}$ \\
\hline $\begin{array}{l}\text { Fialkowski, } \\
\text { DeBaryshe } \\
\text { et al } \\
(2014)(65)\end{array}$ & $\begin{array}{l}\text { US (Alaska, } \\
\text { American } \\
\text { Samoa, Com- } \\
\text { monwealth of } \\
\text { the Northern } \\
\text { Mariana Is- } \\
\text { lands, Guam, } \\
\text { Hawaii; four } \\
\text { communities in } \\
\text { each of these } \\
\text { regions) }\end{array}$ & $\begin{array}{l}\text { To (a), describe the community en- } \\
\text { gagement process (CEP) used by the } \\
\text { Children's Healthy Living (CHL) } \\
\text { Program for remote underserved } \\
\text { minority populations in the USAPI, } \\
\text { Hawaii, and Alaska (b) report com- } \\
\text { munity-identified priorities for an } \\
\text { environmental intervention address- } \\
\text { ing early childhood (ages } 2-8 \text { years) } \\
\text { obesity, and (c) share lessons learned } \\
\text { in the CEP }\end{array}$ & $\begin{array}{l}\text { Participatory } \\
\text { /Empowerment }\end{array}$ & $\begin{array}{l}\text { Problem identi- } \\
\text { fication and } \\
\text { policy formula- } \\
\text { tion }\end{array}$ & $\begin{array}{l}\text { 1.Compile and provide feed- } \\
\text { back (community facilitators, } \\
\text { interview, and survey) }\end{array}$ \\
\hline $\begin{array}{l}\text { Sloane, } \\
\text { Diamant et } \\
\text { al } \\
(2003)(66)\end{array}$ & $\begin{array}{l}\text { US (Los Ange- } \\
\text { les, metropoli- } \\
\text { tan area) }\end{array}$ & $\begin{array}{l}\text { To build health promotion capacity } \\
\text { among community residents through } \\
\text { a community-based participatory } \\
\text { model and to apply this model to } \\
\text { study the nutritional environment of } \\
\text { an urban area to better understand the } \\
\text { role of such resources in the residents' } \\
\text { efforts to live a healthy life }\end{array}$ & $\begin{array}{l}\text { Participatory } \\
\text { /Consult }\end{array}$ & $\begin{array}{l}\text { Problem identi- } \\
\text { fication }\end{array}$ & $\begin{array}{l}\text { Compile and provide feedback } \\
\text { (survey) }\end{array}$ \\
\hline $\begin{array}{l}\text { Karpyn, } \\
\text { Manon et al } \\
(2010)(67)\end{array}$ & $\begin{array}{l}\text { US (Illinois, } \\
\text { Louisiana, and } \\
\text { New York) }\end{array}$ & $\begin{array}{l}\text { Establishment of policy supporting } \\
\text { supermarket development based on } \\
\text { the Pennsylvania model }\end{array}$ & $\begin{array}{l}\text { Participatory } \\
\text { /Empowerment }\end{array}$ & $\begin{array}{l}\text { Problem identi- } \\
\text { fication, policy } \\
\text { formulation, } \\
\text { policy imple- } \\
\text { mentation, and } \\
\text { policy evalua- } \\
\text { tion }\end{array}$ & $\begin{array}{l}\text { 1. Share information (confer- } \\
\text { ence) } \\
\text { 2.Compile and provide feed- } \\
\text { back (mapping and survey) } \\
\text { 3.Bring people together (meet- } \\
\text { ing) }\end{array}$ \\
\hline $\begin{array}{l}\text { Corsino, } \\
\text { McDuffie et } \\
\text { al } \\
(2013)(68)\end{array}$ & $\begin{array}{l}\text { US (Durham, } \\
\text { North Carolina) }\end{array}$ & $\begin{array}{l}\text { Development of plans to improve } \\
\text { health outcomes related to obesity }\end{array}$ & $\begin{array}{l}\text { Participatory } \\
\text { /Empowerment }\end{array}$ & $\begin{array}{l}\text { Problem identi- } \\
\text { fication and } \\
\text { policy formula- } \\
\text { tion }\end{array}$ & $\begin{array}{l}\text { 1.Compile and provide feed- } \\
\text { back (geospatial mapping, } \\
\text { geographic information sys- } \\
\text { tems, and survey) 2.Bring } \\
\text { people together (focus group } \\
\text { interviews) }\end{array}$ \\
\hline $\begin{array}{l}\text { Sharif, } \\
\text { Garza et al } \\
(2015)(69)\end{array}$ & $\begin{array}{l}\text { US (East Los } \\
\text { Angeles) }\end{array}$ & $\begin{array}{l}\text { Mobilizing young people in commu- } \\
\text { nity efforts to improve the food envi- } \\
\text { ronment }\end{array}$ & $\begin{array}{l}\text { Participatory } \\
\text { /Empowerment }\end{array}$ & $\begin{array}{l}\text { Problem identi- } \\
\text { fication }\end{array}$ & $\begin{array}{l}\text { Bringing people together (fo- } \\
\text { cus group interviews) }\end{array}$ \\
\hline
\end{tabular}

plementation phase of studies (28). The collaboration with the community in decision-making process needs sustaining long-term empowerment efforts. Most included studies did not achieve higher levels of community participation.
The importance of financing as an organizational capacity in the success of community participation in policymaking is highlighted in this review and mentioned in other review studies $(29,30)$. The funding of research partnerships is an influential factor in developing CBPR 
Table 2. Successful community participation strategies in food environment policymaking

Community capacity Community participation strategies

building levels

Organizational

structure

- $\quad$ Building community-academic partnership and coalition with local organizations, especially youth who were core agency in applying CBPR principles $(16,32,47,51,63,69)$

- $\quad$ Coalition building with interested and skilled academic members $(16,33,48,50,52)$

- $\quad$ Local capacity building and providing training and learning opportunities (69)

- The use of the social action model for community organizing and coalition building (35)

- The use of an appropriate model to achieve policy-related change and adapt it according to local needs and opportunities $(16,67)$

- The existence of a local advisory group or local expertise of community partners and researchers to help design the study and a consultation on gathering tools and implementing the partnership $(45,61,65)$

- Development of a monitoring system to evaluate the coalition progress by academic partners as external evaluators $(16,50,67)$

- The use of a simple decision-making process to reach consensus (35)

Relationships

Members

Programming

- $\quad$ The use of small tokens and meals/snacks to maintain the involvement of older adults; sustain and provide ongoing opportunities for feedback and input for policy-makers and health agency employees (35)

- Integrating community and academic partners to undertake structured observations during the data collection process (38)

- $\quad$ Trust-building by being present during community events, holding meetings to mutually discuss, walking and driving tours which included the sharing of community stories (33), ongoing communications and formal and informal meetings $(66,68)$, working with strong community leaders, whose contributions are visible to the community $(64,68)$.

- Combination of the research results' dissemination and media coverage for gaining the support of local policymakers $(16,46,52)$.

- Developing a local campaign (the Good Neighbor Program) to reduce tobacco subsidiary food products and replace them with healthier food alternatives (16)

- $\quad$ Giving low-interest loans and energy efficient appliances for involving merchants to store healthy foods (16)

- $\quad$ Engaging key stakeholders through a local advisory committee, key informant interviews, community meetings and community feedback meetings, and developing leadership capacity $(50,52,65)$

- Commitment to long-term funding, advocacy for resolving financial constraints by the presentation of research results and donating time and energy to the project until financial support was received $(16,33,50)$

- $\quad$ Engaging senior advocacy team through advocacy training (47)

- $\quad$ The promotion of co-learning in building a partnership between the university and local community (48)

Using youth organization volunteers (16)

- $\quad$ Recruiting committed, interested, concerned, supportive, and communicative members and strong, trustworthy leaders (64)

- $\quad$ Holding suitable and standard training workshops for members $(32,58-60,66)$

- Using impartial facilitators to promote full participation (65)

- $\quad$ Partnering with cooperative educators (64)

- Using the chain of contact system for an involved and protracted cultural protocol for the recruitment of the participants (65)

- Defining clear goals and sharing for desiring ownership, creating shared mission and vision (50, 52), establishing short-term goals and longer-term targets to maintain members' energy and enthusiasm across long periods (64), emphases on the main purpose as a single unifying goal during the community-engagement process (67, 68)

- $\quad$ Locating service provider at convenience place for community access (48)

- $\quad$ Outlining agreed roles and responsibilities, awareness-raising as a basis for engagement in change policy (52, 64)

- $\quad$ Early engagement of diverse political sectors to achieve policy change to nurture local efforts $(47,67)$

- $\quad$ Tailoring culturally appropriate data collection methods considering the preferences of the participants $(35,38$, $45-47,51-53,59-62,65)$

- Using the local expertise of the community partners and researchers in designing interviews (54) and defining community-led priorities for policy development (65)

- Designing programs according to the ecological framework for behavior change (35)

- The use of an appropriate model in the policy-related process (16). The use of CDC's COCOMO (Common Community Measures for Obesity Prevention guide) to structure in-depth interviews and identify winnable local policy strategies $(55,56)$

- Identifying each community's assets and resources that are related to healthy eating and active living (65)

- $\quad$ Providing appropriate materials, facilities and technical assistance tailored to community needs $(47,50)$

- Applying participatory process and techniques for engaging stakeholders in program planning and implementation (64)

(31). Unreliable funding can create significant obstacles for collaborative working relationships between partners. Tsui et al mentioned that ending grant funding prevented adolescents from completing the action project (32). Alt- hough financial constraints often come up in CBPR projects, in such circumstances, certain communities donate time and energy to the project because of their concerns and commitments $(13,33)$. 
Results showed the importance of using appropriate frameworks for improving the organizational capacity of community in policy-related change. Another review confirmed the effectiveness of applying the openness framework as a conceptual mean for increasing community participation in environment and health issues (34). In a framework developed by Literacy for Environmental Justice (LEJ), a nonprofit youth empowerment and environmental justice education organization, a policy agenda setting that prioritized food security by continuous communication with local policymakers, their research findings on the diverse dimensions of this issue in the neighborhood were presented (16).

Results of the review showed the role of using a simple decision-making process to reach a consensus for improving community organizational capacity. Collaborative consensus building methods use civic dialogue and discourse among parties that allow diverse perspectives to be aired (35). By using this process, decisions can be supported by all the involved parties.

Relationship-building is an arduous task that has consumed immense time and energy on the part of all stakeholders. The relationships between community partners can lead to long-term partnerships that rely on one another (36). Successful community coalitions are associated with internal (eg, relationships across participating members and organizations) and external (eg, connections between the coalition and external entities) relationships (26). Considering the results of this review, positive internal relationships can be shaped through trust-building and continuous communication, and external relationships can be formed through disseminating research achievements and sharing information with external agencies and involving them in advisory committees.

Based on the results, trust-building was among the extracted strategies for improving relationship capacity of community participation in food environment policymaking. Trust can be considered as a key factor in a successful partnership (37). Mabachi et al described a multistage trust-building, which takes much time. During this process, the research team is present to share community stories. Spending time to visit the community and share stories give the team greater insight into the community and make the residents become familiar with the researchers. This helps them to build trust with the key constituencies of local associations as well as community members (33). Results showed a respectful and fun interaction in the data collection process by academic and community partners can develop a positive working climate. It can help to build additional relationships and further develop the capacity for an ongoing partnership, which enhances the quality and the quantity of data (38). The results can form a basis for a systematic review of the effectiveness of proposed trust-building methods in various perspectives.

Results of this review showed using incentives can help improving relationship capacity of community participation in food environment policymaking. Community disengagement may occur in some CBPR projects because of the interest waxes and wanes in longer duration research. Buman et.al suggest using certain incentives such as small tokens (eg, key chains, coffee mugs, etc.) and meals/snacks, which can help engage older adults in CBPR activities. However, a sustained effort with ongoing opportunity for feedback and input is necessary to maintain the involvement (35).

Based on the results of the review, selecting young volunteers can be a beneficial strategy for increasing member capacity of community participation in food environment policymaking. There is a growing momentum of adolescents' participation in the development of policies (39). Young people have the time, the energy, and the passion to lead community movements and may constitute an untapped resource for public health (40). Although few partnerships have involved young people in health policy, their engagement will be the bridge between effective policies and valuable practical action on the ground (41). This shows the importance of involving the youth and youth organizations for increasing the success of CBPR projects focused on the policymaking process.

Another finding of this review was the role of training of members in increasing member capacity of the community for better involvement. In this regard, the Overseas Schools Advisory Council stressed on equipping participants with sufficient knowledge to understand the ideas and the suggestions of the other participants and to develop and share common ideas (42).

Building partnerships require the identification of partners and their unity around a shared vision and a set of goals (43). When the rationale for the project is not as clearly defined, mobilizing community members is not done well (32).

The results of this review showed that for increasing programmatic capacity, applying participatory methods of data collection, planning, and implementation of programs are imperative. Since participatory research places emphasis on conducting research by involving people, the use of suitable means can increase their level of participation. Applying participatory survey methods for gathering data at various stages of policymaking make respondents more motivated and provide higher quality data (44). Using easy-to-use tools such as photo-voice, observational checklists, and mapping with completion manuals, an operational definition of unclear terms, can result in capacity-building and increase the sense of ownership and accountability $(35,45)$.

The use of local expertise of community partners in the formulation and prioritization of policies was extracted as a beneficial strategy for increasing the programmatic capacity of community participation in food environment policymaking in reviewed articles. Motivating and recognizing their knowledge can increase their sense of belonging and engagement (45).

Results of this review revealed that the use of a framework for behavior and policy-related changes can be effective in promoting program capacity of community participation. In this regard, the LEJ organization presented an example of a successful model of how the partnership between an academic partner with nonprofit youth empowerment and environmental justice education organization can be established for the translation of basic research 
into practice and interventions to improve the food environment. This organization proposed that elements such as effective leadership, formalized procedures, effective communication, sufficient resources, and continuous improvement can result in a stable collaborative working group and lead to long-term partnerships to develop community accessibility to healthy food(16).

The main limitation of this review was that only published peer-reviewed journal articles were included in the review; grey literature and those studies which were published in conferences, books, and organizational reports were not considered. Another limitation was that included studies in this review were mainly conducted in the US; thus, the generalizability of the results to other countries, particularly to developing and underdeveloped countries, is limited.

\section{Conclusion}

To improve the food environment and people's health using the community-participation approach, identifying successful strategies and adjusting them based on the social and political context of each society is necessary. Thus, further assessment and systematic reviews should be conducted on the effectiveness of the proposed strategies.

\section{Acknowledgments}

This research was supported by Iran University of Medical Sciences. We would like to thank Dr. Behzad Damari for his technical help.

\section{Conflict of Interests}

The authors declare that they have no competing interests.

\section{References}

1. Escaron AL. Supermarket and grocery store-based interventions to promote healthful food choices and eating practices: a systematic review. Prev Chronic Dis. 2013;10.

2. Van Der Horst K, Oenema A, Ferreira I, Wendel-Vos W, Giskes K, van Lenthe F, et al. A systematic review of environmental correlates of obesity-related dietary behaviors in youth. Health Educ Res. 2007;22(2):203-26.

3. Walker RE, Keane CR, Burke JG. Disparities and access to healthy food in the United States: A review of food deserts literature. Health Place. 2010;16(5):876-84.

4. Sallis JF, Owen N, Fisher EB. Ecological models of health behavior. Health behavior and health education: Theory, research, and practice. 2008;4:465-86.

5. Bell J, Mora G, Hagan E, Rubin V, Karpyn A. Access to healthy food and why it matters: A review of the research. Philadelphia, PA: The Food Trust. 2013.

6. Zenk SN, Schulz AJ, Israel BA, James SA, Bao S, Wilson ML. Fruit and vegetable access differs by community racial composition and socioeconomic position in Detroit, Michigan. Ethn Dis. 2005;16(1):275-80.

7. Jetter KM, Cassady DL. The availability and cost of healthier food alternatives. Am J Prev Med. 2006;30(1):38-44.

8. Morland K, Filomena S. Disparities in the availability of fruits and vegetables between racially segregated urban neighbourhoods. Public Health Nutr. 2007;10(12):1481-9.

9. Li F, Harmer P, Cardinal BJ, Bosworth M, Johnson-Shelton D. Obesity and the built environment: does the density of neighborhood fast-food outlets matter? Am J Health Promot. 2009;23(3):203-9.

10. Kwate NOA, Loh JM. Separate and unequal: the influence of neighborhood and school characteristics on spatial proximity between fast food and schools. Prev Med. 2010;51(2):153-6.

11. Bodor JN, Ulmer VM, Dunaway LF, Farley TA, Rose D. The rationale behind small food store interventions in low-income urban neighborhoods: insights from New Orleans. J Nutr. 2010;140(6):1185-8

12. Health UDo, Services H. US Department of Agriculture. Dietary Guidelines Advisory Committee. Report of the Dietary Guidelines Advisory Committee on the Dietary Guidelines for Americans, 2005. January 2005. Agricultural Research Service. 2010.

13. Minkler M. Linking science and policy through community-based participatory research to study and address health disparities. Am J Public Health. 2010;100(S1):S81-S7.

14. Wallerstein N, Duran B. Community-based participatory research contributions to intervention research: the intersection of science and practice to improve health equity. Am J Public Health. 2010;100(S1):S40-S6.

15. Shaffer A, Vallianatos M, Azuma AM, Gottlieb R. Changing the food environment: community engagement strategies and place-based policy tools that address the influence of marketing. Loy LAL Rev. 2006;39:647.

16. Vásquez VB, Lanza D, Hennessey-Lavery S, Facente S, Halpin HA, Minkler M. Addressing food security through public policy action in a community-based participatory research partnership. Health Promot Pract. 2007;8(4):342-9.

17. Johnson-Shelton D, Moreno-Black G, Evers C, Zwink N. A community-based participatory research approach for preventing childhood obesity: The communities and schools together project. Prog Commun Health Partner. 2015;9(3):351.

18. Renzaho A. Dissecting and customising the Childhood Obesity Prevention Advisory Council (COPAC): the development and application of a community engagement framework to improve childhood obesity prevention among migrant populations. Glob Health Act. 2017;10(1):1321822.

19. Arksey H, O'Malley L. Scoping studies: towards a methodological framework. Int J Soc Res Methodol. 2005;8(1):19-32.

20. Levac D, Colquhoun H, O'Brien KK. Scoping studies: advancing the methodology. Implement Sci. 2010;5(1):69.

21. Peters M, Godfrey C, McInerney P, Soares C, Hanan K, Parker D. The Joanna Briggs Institute Reviewers' Manual 2015: Methodology for JBI Scoping Reviews. 2015.

22. Jones CO. An Introduction to the Study of Public Policy (Belmont, Calif.: Wadsworth). Inc; 1984.

23. IAP2 IAfPP-. IAP2 Spectrum of Public Participation 2009 [cited 12 Sep 2009]. Available from: http://iap2canada.ca/page-1020549.

24. IAP2 IAfPP-. IAP2's PUBLIC PARTICIPATION TOOLBOX 2006. Available from: http://c.ymcdn.com/sites/www.iap2.org/resource/ resmgr/imported/toolbox.pdf.

25. Fookes T. Public Participation and Consultation within the RMA. Local Authorities Upskilling Project Workshop Manual. Auckland, New Zealand: Department of Planning, University of Auckland; 1996.

26. Foster-Fishman PG, Berkowitz SL, Lounsbury DW, Jacobson S, Allen NA. Building collaborative capacity in community coalitions: A review and integrative framework. Am J Commun Psychol. 2001;29(2):241-61.

27. Hsieh HF, Shannon SE. Three approaches to qualitative content analysis. Qual Health Res. 2005;15(9):1277-88.

28. Salimi Y, Shahandeh K, Malekafzali H, Loori N, Kheiltash A, Jamshidi E, et al. Is community-based participatory research (CBPR) useful? A systematic review on papers in a decade. Int J Prev Med. 2012;3(6):386

29. Pratchett L, Durose C, Lowndes V, Smith G, Stoker G, Wales C. Empowering communities to influence local decision making: systematic review of the evidence. 2009.

30. Chirenje LI, Giliba RA, Musamba EB. Local communities' participation in decision-making processes through planning and budgeting in African countries. Chinese J Pop Res Environ. 2013;11(1):10-6.

31. Israel BA, Schulz AJ, Parker EA, Becker AB. Community-based participatory research: policy recommendations for promoting a partnership approach in health research. Educ Health. 2001;14(2):182-97.

32. Tsui E, Bylander K, Cho M, Maybank A, Freudenberg N. Engaging youth in food activism in New York City: lessons learned from a 
youth organization, health department, and university partnership. J Urban Health. 2012;89(5):809-27.

33. Mabachi NM, Kimminau KS. Leveraging community-academic partnerships to improve healthy food access in an urban, Kansas City, Kansas, community. Prog Commun Health Partner. 2012;6(3):27988.

34. Pohjola MV, Tuomisto JT. Openness in participation, assessment, and policy making upon issues of environment and environmental health: a review of literature and recent project results. J Environ Health. 2011;10(1):58

35. Buman MP, Winter SJ, Baker C, Hekler EB, Otten JJ, King AC. Neighborhood Eating and Activity Advocacy Teams (NEAAT): engaging older adults in policy activities to improve food and physical environments. Transl Behav Med. 2012;2(2):249-53.

36. Saltiel IM. Defining collaborative partnerships. New Dir Adult Cont Educ. 1998;1998(79):5-11.

37. Simpson JA. Psychological foundations of trust. Curr Dir Psychol Sci. 2007;16(5):264-8.

38. Kleinman LC, Lutz D, Plumb EJ, Barkley P, Nazario HR, Ramos MA, et al. A partnered approach for structured observation to assess the environment of a neighborhood with high diabetes rates. Prog Commun Health Partner. 2011;5(3):249.

39. Group DCYW. Youth participation in development: A guide for development agencies and policy makers. London: DFID-CSO Youth Working Group. 2010.

40. Checkoway BN, Gutierrez LM. Youth participation and community change: An introduction. J Commun Pract. 2006;14(1-2):1-9.

41. Gero A, Asker S. The Role of Child and Youth Participation in Development Effectiveness: A literature review. 2012.

42. Council OSA. Count Me In - Developing Inclusive International Schools. Washington, D.C: US Department of State; 2004.

43. Roussos ST, Fawcett SB. A review of collaborative partnerships as a strategy for improving community health. Ann Rev Public Health. 2000;21(1):369-402.

44. Norway s. Strategy for data collection. Norway: 2007.

45. Skinner K, Hanning RM, Tsuji LJ. Barriers and supports for healthy eating and physical activity for First Nation youths in northern Canada. Int J Circumpolar Health. 2006;65(2).

46. Díez J, Conde P, Sandin M, Urtasun M, López R, Carrero JL, et al. Understanding the local food environment: A participatory photovoice project in a low-income area in Madrid, Spain. Health Place. 2017;43:95-103.

47. Sheats JL, Winter SJ, Romero PP, King AC. FEAST: empowering community residents to use technology to assess and advocate for healthy food environments. J Urban Health. 2017;94(2):180-9.

48. Ball L, McCauley A, Paul T, Gruber K, Haldeman L, Dharod J. Evaluating the Implementation of a Farmers' Market Targeting WIC FMNP Participants. Health Promot Pract. 2018;19(6):946-56.

49. Lachance L, Quinn M, Kowalski-Dobson T. The Food \& Fitness Community Partnerships: Results From 9 Years of Local Systems and Policy Changes to Increase Equitable Opportunities for Health. Health Promot Pract. 2018;19(1_suppl):92s-114s.

50. Lachance L, Quinn M, Kowalski-Dobson T. The food \& fitness community partnerships: Results from 9 years of local systems and policy changes to increase equitable opportunities for health. Health Promot Pract. 2018;19(1 suppl):92S-114S

51. Leung MM, Agaronov A, Entwistle T, Harry L, Sharkey-Buckley J, Freudenberg N. Voices through cameras: Using photovoice to explore food justice issues with minority youth in East Harlem, New York. Health Promot Pract. 2017;18(2):211-20.

52. Minkler M, Estrada J, Thayer R, Juachon L, Wakimoto P, Falbe J. Bringing healthy retail to urban "food swamps": a case study of CBPR-informed policy and neighborhood change in San Francisco. J Urban Health. 2018;95(6):850-8.

53. Buman MP, Bertmann F, Hekler EB, Winter SJ, Sheats JL, King $\mathrm{AC}$, et al. A qualitative study of shopper experiences at an urban farmers' market using the Stanford Healthy Neighborhood Discovery Tool. Public Health Nutr. 2015;18(06):994-1000.

54. Gravlee CC, Boston PQ, Mitchell MM, Schultz AF, Betterley C.
Food store owners' and managers' perspectives on the food environment: an exploratory mixed-methods study. BMC Public Health. 2014;14(1):1031

55. Pitts SBJ, Smith TW, Thayer LM, Drobka S, Miller C, Keyserling $\mathrm{TC}$, et al. Addressing rural health disparities through policy change in the stroke belt. J Public Health Manag Pract. 2013;19(6):503.

56. Pitts SBJ. A community-driven approach to identifying "winnable" policies using the Centers for Disease Control and Prevention's Common Community Measures for Obesity Prevention. Prev Chronic Dis. 2012;9.

57. Byrd-Bredbenner C, Johnson M, Quick VM, Walsh J, Greene GW, Hoerr S, et al. Sweet and salty. An assessment of the snacks and beverages sold in vending machines on US post-secondary institution campuses. Appetite. 2012;58(3):1143-51

58. Noseworthy BL, Williams PL, Blum I, MacLeod M. The availability and relative cost of locally produced foods in grocery stores in Nova Scotia. J Hunger Environ Nutr. 2011;6(2):188-206.

59. Izumi BT, Zenk SN, Schulz AJ, Mentz GB, Sand SL, De Majo RF, et al. Inter-rater reliability of the food environment audit for diverse neighborhoods (FEAD-N). J Urban Health. 2012;89(3):486-99.

60. Azuma AM, Gilliland S, Vallianatos M, Gottlieb R. Food access, availability, and affordability in 3 Los Angeles communities, Project CAFE, 2004-2006. 2010.

61. Fleischhacker S, Vu M, Ries A, McPhail A. Engaging tribal leaders in an American Indian healthy eating project through modified talking circles. Fam Commun Health. 2011;34(3):202-10.

62. Jernigan VBB, Salvatore AL, Styne DM, Winkleby M. Addressing food insecurity in a Native American reservation using communitybased participatory research. Health Educ Res. 2011:cyr089.

63. Hill JL. Lack of healthy food options on children's menus of restaurants in the health-disparate Dan River region of Virginia and North Carolina, 2013. Prev Chronic Dis. 2015;12.

64. Seguin RA, Folta SC, Sehlke M, Nelson ME, Heidkamp-Young E, Fenton M, et al. The StrongWomen change clubs: engaging residents to catalyze positive change in food and physical activity environments. J Environ Public Health. 2014;2014.

65. Fialkowski MK, DeBaryshe B, Bersamin A, Nigg C, Guerrero RL, Rojas G, et al. A community engagement process identifies environmental priorities to prevent early childhood obesity: the children's healthy living (CHL) program for remote underserved populations in the US affiliated pacific islands, Hawaii and Alaska. Matern Child Health J. 2014;18(10):2261-74

66. Sloane DC, Diamant AL, Lewis LB, Yancey AK, Flynn G, Nascimento LM, et al. Improving the nutritional resource environment for healthy living through community-based participatory research. J Gen Intern Med. 2003;18(7):568-75.

67. Karpyn A, Manon M, Treuhaft S, Giang T, Harries C, McCoubrey K. Policy solutions to the 'grocery gap'. Health Aff . 2010;29(3):47380.

68. Corsino L, McDuffie JR, Kotch J, Coeytaux R, Fuemmeler BF, Murphy G, et al. Achieving Health for a Lifetime: A Community Engagement Assessment Focusing on School-Age Children to Decrease Obesity in Durham, North Carolina. N C Med J. 2013;74(1):18

69. Sharif MZ, Garza JR, Langellier BA, Kuo AA, Glik DC, Prelip ML, et al. Mobilizing young people in community efforts to improve the food environment: Corner store conversions in East Los Angeles. Public Health Rep. 2015;130(4):406-15. 
Appendix 1. Search syntaxes in databases

\section{PubMed}

(community participat*[tiab] OR community engag*[tiab] OR participatory action research[tiab] OR community based participat*[tiab]) AND (food access*[tiab] OR food availab*[tiab] OR food affordab*[tiab] OR food environment[tiab]) AND 1990/01/01:2018/12/31[dp] Sort by: Best Match Filters: English

Scopus

(TITLE-ABS(community participat*) OR TITLE-ABS(community engag*) OR TITLE-ABS(participatory action research) OR TITLEABS(community based participat*)) AND (TITLE-ABS(food access*) OR TITLE-ABS(food availab*) OR TITLE-ABS(food affordab*) OR TITLEABS(food environment)) AND (PUBYEAR > 1989 AND PUBYEAR < 2019) AND ( LIMIT-TO ( DOCTYPE,"ar" ) ) AND ( LIMIT-TO ( LANGUAGE,"English" ) )

Web of Science

((TS=(community participat*) OR TS=(community engag*) OR TS=(participatory action research) OR TS=(community based participat*) $\mathrm{AND}$ $(\mathrm{TS}=($ food access* $)$ OR TS $=($ food availab*) OR TS $=($ food affordab* $)$ OR TS=(food environment $))$ AND PY=(1990-2018) $)$ AND LANGUAGE: $($ English) AND DOCUMENT TYPES: (Article) 